\title{
Watershed Evaluation and Farmers' Preference - An Experience from Watershed Projects in Karnataka (India)
}

\author{
Bhupendra Singh Naik*, Sekhargouda Lingannagouda Patil, Anurag Raizada, \\ Hrittick Biswas, Suresh Kumar, Mundre Ningappa Ramesha, Wontakal Muralidhar, \\ Keshava Kumar Reddy and P. Mohan Kumar
}

ICAR-Indian Institute of Soil and Water Conservation (IISWC), Research Centre, Hospet
Road, Ballari-583104, Karnataka, India

*Corresponding author

\begin{tabular}{|l|} 
Ke y w o r d s \\
$\begin{array}{l}\text { Conservation measures, } \\
\text { Fixed point scoring and } \\
\text { rating method, Land } \\
\text { degradation, Natural } \\
\text { resource management, } \\
\text { Soil erosion }\end{array}$ \\
\hline Article Info \\
\hline $\begin{array}{l}\text { Accepted: } \\
\text { 18 August } 2018 \\
\text { Available Online: } \\
\text { 10 September } 2018\end{array}$ \\
\hline
\end{tabular}

\section{Introduction}

Soil and water are essential natural resources
that support life on earth but they are
continuously diminishing and threatened due
to various biotic factors. Runoff induced soil

Soil and water are essential natural resources
that support life on earth but they are
continuously diminishing and threatened due
to various biotic factors. Runoff induced soil

Soil and water are essential natural resources
that support life on earth but they are
continuously diminishing and threatened due
to various biotic factors. Runoff induced soil

Soil and water are essential natural resources
that support life on earth but they are
continuously diminishing and threatened due
to various biotic factors. Runoff induced soil

\section{A B S T R A C T}

Twelve watershed projects located in six distressed districts of Karnataka (India) were evaluated. Various soil and water conservation (SWC) measures were implemented in the watersheds by concerned project implementing agencies (PIAs). Many lacunas and technical errors were observed in respect of executed SWC measures in the field while carrying out the evaluation work. Field observations on SWC measures related to site suitability, catchment, adequacy of design, quality, stability, siltation, vegetation, etc. are presented in this paper. In addition, the overall impact of SWC measures on watershed hydrology, productivity, erosion control and economics are also discussed along with farmers' preference for SWC measures. The expenditure towards watershed treatments varied from Rs 2429 to Rs 7616 per hectare. Field bunding was the major activity in 9 watersheds involving expenditure of $40-83 \%$ of total amount spent. Economic analysis revealed that maintenance of the SWC structures in the watersheds for 15 years can result higher BC ratios and IRR. As far as farmers' preference is concerned, field bunding was most preferred among SWC measures followed by check dam, farm pond and trenching. Among different ameliorating effects of SWC activities, highest weight was given to crop yield by farmers. It indicates that farmers give more priority to economic return as compared to other tangible benefits while adopting SWC measures. Waste weir was least preferred and it might be due to less rainfall and rare instance of water impoundment in the field up to highest flood level. As a result of implementation of SWC engineering measures across watersheds, a total of 2, 63,706 man days of direct employment was generated which curbed the migration to a large extent. erosion and land degradation is the most serious and prevalent problem now all over the world. It is estimated that about $80 \%$ of the current degradation on agricultural land in the world is caused by soil erosion due to water (Angima et al., 2003). Land degradation has 
been a major global agenda because of its adverse impact on environment and food security and on the quality of life (Slegers, 2008). In India, based on a harmonized database of land degradation, an area of $120.72 \mathrm{~m}$ ha (about $37 \%$ of the geographical area) is subjected to various forms of land degradation and among the different categories, water erosion is the highest contributor (68.4\%) (NAAS-ICAR, 2010). Soil erosion leads to loss of soil fertility and decline in crop productivity. Sharda et al., (2010) estimated an annual loss of 13.4 million tonnes in the production of major cereal, oilseed and pulse crops in India due to water erosion, equivalent to a loss in revenue of about \$ 2.51 billion. From a study in eastern ghat region of India, Naik et al., (2015) reported annual soil loss of 13.34 million tonnes from the cultivable area at the rate of $43.86 \mathrm{t} \mathrm{ha}^{-1} \mathrm{yr}^{-1}$ and they mentioned that soil loss is a menace to agriculture and it is to be tackled properly with the adoption of suitable conservation measures. Productive land is the source of human sustenance and security and in order to keep the land productive, adoption of soil and water conservation practices is imperative.

Soil and water conservation measures help in rehabilitation of land impoverished by erosion and overuse. It makes land more productive and sustainable so that its carrying capacity is increased. A watershed is an attractive unit for technical efforts to conserve soil and maximize utilization of surface and subsurface water for crop production (Kerr et al., 2000). Both central and state governments and international donors have been implementing watershed development programmes across the country in different modes. The overall objectives of these development programmes, by and large, are three fold, viz. promoting economic development of rural areas, employment generation, and restoring ecological balance (Department of Land
Resources, 2006). Wani et al., (2001) reported significant impact of watershed management on crop production, increase in ground water level, reduction in runoff water, increase in income, etc. Management of natural resources at watershed scale produces multiple benefits in terms of increasing food production, improving livelihoods, protecting environment, addressing gender and equity issues along with biodiversity concerns (Joshi et al., 2005). Watershed management is a holistic approach to improve and develop the economic and natural resource base of dry and semiarid regions (Ninan and Lakshmikanthamma, 2001). Schilling and Helmers (2008) reported that there was rise in water table and depth of water storage in well in the Lowa watershed areas due to increased base flow as a result of implementation of soil and water conservation measures. Studies by Deshpande and Reddy (1991), Dhyani et al., (2001), Shah (2001), Wani et al., (2003), Joshi et al., (2004), Rockstrom et al., (2007), Joshi et al., (2008), Dass et al., (2009), Palanisami and Kumar (2009), Madhu et al., (2016) and others have acknowledged that watershed development programmes have potential to augment agricultural productivity, income, and employment generation in the watershed.

For soil and water conservation, different treatment measures are implemented in watershed separately for arable and non-arable lands. In arable lands, mostly bunding, bench terracing, trenching, conservation bench terracing, zing terracing, conservation ditching, stone wall, etc., are implemented as per the site suitability. In non-arable lands, it involves diversion drains, contour trenching, contour wattling, retaining walls, crib structures, geotextiles, drainage line treatment measures i.e. brush wood check dam, loose boulder check dam/structures, gully plugs, gabion check dam, drop structures / masonry check dam etc. In addition, water harvesting structures (farm ponds and percolation tanks), 
crop demonstration, horticulture plantation, afforestation etc. are also carried out in watershed. Such activities have become an established strategy in watershed development for resource management.

For their effectiveness, proper planning and implementation should be done as per the need and site suitability to fit conservation practices and structures. However, the success of watershed development depends on the stake holder participation (Fadim and Baycan, 2015). The watershed programme should be evaluated after their completion to assess the efficiency, sustainability, acceptability and overall impact of SWC activities. In the context of above, an evaluation was carried out covering 12 completed watershed projects located in six distressed districts of Karnataka and is reported in this paper. These projects were implemented through designated NGOs funded by National Bank for Agriculture and Rural Development (NABARD). More importance was given to SWC measures for the evaluation. For assessing the farmers' preference for soil and water conservation practices, multiple objective decision support (MODS) weighting techniques were used.

\section{Materials and Methods}

\section{Study area}

Six districts viz. Belgaum, Chitradurga, Chikmagalur, Hassan, Kodagu and Shimoga, identified as distressed districts of Karnataka by Govt. of India were covered under the present study. A total of 12 representative watersheds from these districts viz. Attibylu and Shedgar (Shimoga), Baladare and Gandasi (Hassan), Bukkasagar and Sukaligarahatti (Chikmagalur), Harohalli and Laxmanthirtha (Kodagu), Herekumbi and Wadral (Belgaum), Herurkerenala and Sugoor (Chitradurga) were evaluated. The location map of said 12 watersheds is given in Figure 1.
The geographical area, rainfall scenario and prevalent problems of each watershed are given in Table 1.

For the evaluation purpose, detailed information on treatment measures and other activities taken up in the watersheds as given in detailed project reports (DPR) and final project completion reports provided by the concerned project implementing agencies (PIAs) were compared with the field implementation status. The information and feedback on present status of SWC measures in all the watersheds were collected by direct observation through field visits and by taking individual and group interviews of stake holders by a team consisting of multidisciplinary scientists and technical staff. Prior to field visits, the team had comprehensive discussions with the concerned NGO officials (PIAs) on different activities carried out by the latter in watersheds. The evaluation team accompanied by the concerned NGO officials for inspection of sites where structures/measures were implemented. The beneficiaries were selected randomly as per their land revenue survey numbers for verifying the existence and measurements of structures on the spot.

Direct observations on site suitability, adequacy of catchment area, design, quality, stability, decrease in erosion, siltation etc. in respect of all the structures were taken at the site itself. As a result of implementation of SWC measures the overall change in watershed i.e. hydrology, erosion scenario, productivity etc. were also assessed from visual observation on field measurements and feedback of stake holders since no gauging devices were used for monitoring the impact. In the absence of gauging devices, soil loss was estimated indirectly from volume of the sediment deposition in the upstream of SWC measures using depth and localized area of siltation, and multiplying it with bulk density 
of sediment. Since the approximate catchment of runoff is known for the said quantity of sediment loss, the soil loss is determined accordingly per unit ha area. The soil loss estimated was compared with soil loss already estimated by ICAR-IISWC, Research Centre, Bellary (Karnataka) to calculate the reduction in soil loss in the absence of pre-project information. Organic carbon content in soil was determined following the wet digestion method of Walkley and Black (1934).

Multiple objective decision support (MODS) weighting technique employing Fixed point scoring and Rating method (Hajkowicz et al., 2000) was used here to assess the preferences of farmers for adopting various SWC practices to meet multiple objectives/criteria. Under these methods, a higher point/percentage score indicates that the criterion has greater importance (Nijkamp et al., 1990). Fixed point scoring is the direct means of obtaining weighting information from the decision makers and they distribute fixed number of points among criteria. In case of Rating technique, the weights are obtained on a scale i.e. 1-5, 1-7 or 1-10 and ranges from least important to most important to represent the criteria (Nijkamp et al., 1990). Here for the evaluation purpose, some defined criteria were selected after discussion with farmers as per their preference of SWC measures. The criteria selected were reduced soil loss, improved soil fertility, retained soil moisture, improvement ground water level, increased crop yield, increased fodder, maximized cultivable land, low labour requirement, easy and less maintenance. These criteria reflect the advantages and disadvantages of different SWC practices (Adimassu et al., 2013). The feedback on above selected criteria was taken from 50 beneficiaries/farmers of each watershed for the analysis.

Economic analysis was done keeping in view to have optimum potential benefits and sustainability of SWC structures in the watershed through regular repair and maintenance work. For initial investments on the SWC measures, cost of supplementary inputs and demonstrations were considered.

Economic indicators i.e. benefit cost (BC) ratio and internal rate of return (IRR) were computed using standard available procedure (Boardman et al., 2006; Ginttinger, 1994, Gramlich, 1997; Jenkins et al., 2011) at 12 and $15 \%$ discount rates for 10 and 15 years period. The present value of all the benefits and costs was used for computing the $\mathrm{BC}$ ratio and IRR. Computation of IRR was done by using SOLVER option in excel.

\section{Results and Discussion}

\section{Types of SWC measures implemented}

Different soil and water conservation activities observed in all the 12 watersheds include field bunding/trench cum bund, waste weirs, staggered contour trenching, diversion channels, farm ponds and drainage line treatments (DLTs) i.e. boulder checks, rubble checks, vented and masonry check dams etc.

The major activity of field bunding was implemented in nine watersheds with mild land sloping conditions (2-8\%) followed by staggered contour trenching (SCT) in two watersheds with steep slopes (> 25\%) and undulating topography, and diversion channels in one watershed to deal with severe water stagnation problem. The details of watershedwise activities taken are given in Table 2.

\section{Design, location suitability and performance of major SWC measures}

\section{Bunding}

The field bunds were constructed in watersheds with cross sections of $0.54 \mathrm{~m}^{2}$ in 
Attibylu, Baladare, Bukkasagar, Herurkerenala and Sugoor having red soils, $0.45 \mathrm{~m}^{2}$ in Gandasi and Sukaligarahatti having red soils, $0.92 \mathrm{~m}^{2}$ in Herekumbi having black soils and $0.72 \mathrm{~m}^{2}$ in Wadral having black soils. In case of field bunds/trench cum bunds, no proper vertical interval (VI), horizontal interval (HI), cross section and uniformity were maintained. In most of the watersheds, it was noticed that old field bunds were only strengthened by putting trench excavated soil over it. Due to under design in black soils, most of the filed bunds were found damaged. It was also reported that all the bunding work was carried out by mechanical means using Excavator.

\section{Trenching}

Staggered contour trenching (SCT) had been implemented intensively in hill slopes of two watersheds viz. Harohalli and Laxmanthirtha with cross sections of 0.24 and $0.18 \mathrm{~m}^{2}$, respectively and coffee plantations were supported by it.

The design cross section of SCT was found to be adequate but proper VI was not maintained. At some places the trenches were made in columnar way just behind one another and no staggered way was followed.

\section{Waste weir}

Many of the waste weirs constructed in farmers' fields were observed to have been damaged and defunct due to faulty design, poor quality construction and improper site selection.

But in black soil, where the pipe waste weirs are constructed, they were observed to be working very effectively. In few places, pipe outlets were also found damaged due to poor quality, improper size and heavy scouring in the downstream due to absence of apron.

\section{Farm pond}

Farm ponds of four different sizes i.e. $7 \mathrm{~m} \times 7$ $\mathrm{m} \times 3 \mathrm{~m}, 9 \mathrm{~m} \times 9 \mathrm{~m} \times 3 \mathrm{~m}, 10 \mathrm{~m} \times 10 \mathrm{~m} \times 3 \mathrm{~m}$ and $12 \mathrm{~m} \times 12 \mathrm{~m} \times 3 \mathrm{~m}$ were constructed in all twelve watersheds. In most of the farm ponds, the sites of construction and catchments were not proper. Due to absence of appropriate side slopes, inlets, silt traps and outlets, it led to reduced runoff storage, damage of sides and heavy siltation in farm ponds. As a result, about $60 \%$ of the farm ponds were found either non-functional or damaged.

\section{Drainage line treatments}

In watersheds, the design and quality of construction in case of check dams were adequate but most of the check dams had been constructed at wrong sites with limited command area and were not fully serving the purpose. Boulder checks (BC) and rubble checks (RC) with cross sections of $0.45,0.54$ and $0.90 \mathrm{~m}^{2}$ were constructed limited to three watersheds (Gandasi, Sukaligarahatti and Harohalli) at suitable sites on the drainage lines but neither uniform sized stones used for construction nor proper aprons were provided in most cases. As a result, some such structures were damaged due to excess scouring in the downstream area and uprooted. Some DLT structures were under-designed due to restrictions on expenditure per unit area by the funding agency. Visible siltation and vegetation establishment were observed near all the DLT structures. No drainage line treatment (DLT) measures were taken in Wadral watershed which resulted in high soil erosion from upper catchment and formation of more gullies in the downstream areas.

\section{Waterways}

Since high rainfall and problem of water logging is there in Harohalli, Laxmanthirtha and Shedgar watersheds, waterways with 
channel cross sections of 0.45 and 0.24 $\mathrm{m}^{2}$ were constructed extensively for safe disposal of runoff. It was observed that the waterways were poorly maintained with no uniform cross sections, side slopes and found damaged in many places due to under design and poor construction.

\section{Shallow wells}

In Hirekumbi watershed, shallow wells were constructed in farmers' field. It was observed that these were all developed, extended and deepened wells with abundant water availability due to presence of hard rock geology. All the shallow wells were observed to be well maintained and fed by adjacent grass water ways. Shallow wells were solely used for irrigation purposes by the farmers.

\section{Diversion channel}

Diversion channel (DC) was the major activity implemented in Shedgar watershed. The design cross section of channel $\left(0.54 \mathrm{~m}^{2}\right)$ was adequate for the purpose of effective diversion of runoff from the uplands to avoid damage of agricultural lands in the downstream.

It was apparent from the field observation that the implementing agencies had ignored the expected peak rate of runoff from the catchment while undertaking the construction of above structures, where as it is an important factor for ascertaining the structural stability and sustainability. Thus, as a result many structures were found partially damaged and there is a possibility of failure of structures under unexpected heavy storm events in future. In 9 watersheds, as the rainfall received is below $800 \mathrm{~mm}$, contour bunding should have been done with VI of $1 \mathrm{~m}$ to intercept the runoff instead of implementing simple field bunds/trench-cum-bunds. The cross sections adopted i.e. $0.45 \mathrm{~m}^{2}, 0.92 \mathrm{~m}^{2}$ and $0.72 \mathrm{~m}^{2}$ in respective watersheds are not adequate as soil types varies among watersheds and within the watershed. So adopting a uniform bund cross section in a watershed is not technically sound. In Hirekumbi and Wadral watershed, the cross section of field bunds should be within 1.0 to $1.2 \mathrm{~m}^{2}$ for better stability due to prevalence of black soils. In case of deep black clay soil, graded bunding should have been done for disposal of excess runoff during heavy storms. The minimum cross sections of bunds recommended for the red and black soils are $0.54 \mathrm{~m}^{2}$ and $1 \mathrm{~m}^{2}$ (Sharda et al., 2007). It is experienced from field observation that in red soils, optimum cross section of 0.62 $\mathrm{m}^{2}$ should be adopted for more life and durability.

In case of staggered contour trenching, higher trench density was observed due to improper VI which is not required and not economical suitable. The trench density and VI should be decided as per the volume of runoff to be captured and slope of the catchment. For farm pond construction, site with preferably black soil with natural depression, crop water requirement, dependable rainfall and runoff from catchment should be considered. Side slope of 1.5:1 in black soil and 1:1 in red soil to be provided along with provision of silt trap, inlet, and outlet for better stability and protection from damage.

\section{Physical and financial achievement}

As far as physical achievement (area treated) of 12 watershed projects was concerned, it was found varied from $59-100 \%$.The average expenditure incurred for treatment of 1 ha area in 8 watersheds was within the then funding norms as per Govt. Common Watershed Guidelines (Rs 6000/ha). In four watersheds it exceeded and varied from Rs 6322 to Rs 7416. Highest and lowest expenditure was incurred in case of Herurkerenala (Rs 7416/ ha) and Harohali watershed (Rs 2429/ ha) for watershed treatment. 
Table.1 Geographical area, agro-climatic zone, soil types, rainfall scenario and prevalent problems of watersheds selected

\begin{tabular}{|c|c|c|c|}
\hline $\begin{array}{c}\text { Name of } \\
\text { watershed and } \\
\text { geographical area } \\
\text { (ha) }\end{array}$ & $\begin{array}{l}\text { Name of Agro- } \\
\text { climatic zone } \\
\text { (Karnataka) }\end{array}$ & $\begin{array}{c}\text { Major soil } \\
\text { type, and } \\
\text { Rainfall }(\mathrm{mm})\end{array}$ & Prevalent problems \\
\hline $\begin{array}{l}\text { Attibylu } \\
(1263.09)\end{array}$ & $\begin{array}{l}\text { Southern } \\
\text { Transition Zone }\end{array}$ & $\begin{array}{l}\text { Red soil, } \\
(650)\end{array}$ & $\begin{array}{l}\text { Erratic rainfall, soil erosion, land degradation, } \\
\text { drought, deforestation, low soil fertility and } \\
\text { poor productivity. }\end{array}$ \\
\hline $\begin{array}{l}\text { Shedgar } \\
(1302.56)\end{array}$ & Hilly Zone & $\begin{array}{l}\text { Red soil, } \\
\text { (2800 to } 3000)\end{array}$ & $\begin{array}{l}\text { Undulating topography, intense rainfall and } \\
\text { heavy runoff, high soil erosion, decreased } \\
\text { productivity and poor drainage in low land } \\
\text { areas. }\end{array}$ \\
\hline $\begin{array}{l}\text { Baladare } \\
(1294.81)\end{array}$ & $\begin{array}{l}\text { Southern Dry } \\
\text { Zone }\end{array}$ & $\begin{array}{l}\text { Red soil, } \\
\text { ( } 650 \text { to } 750)\end{array}$ & $\begin{array}{l}\text { Undulating landscape, soil erosion, land } \\
\text { degradation, water scarcity and low } \\
\text { productivity }\end{array}$ \\
\hline $\begin{array}{l}\text { Gandasi } \\
(1162.30)\end{array}$ & $\begin{array}{l}\text { Central Dry } \\
\text { Zone }\end{array}$ & $\begin{array}{l}\text { Red soil, } \\
\text { (700 to } 750)\end{array}$ & $\begin{array}{l}\text { Undulating and slopy land, soil erosion, low } \\
\text { soil moisture, water scarcity and poor } \\
\text { productivity. }\end{array}$ \\
\hline $\begin{array}{l}\text { Bukkasagar } \\
\text { (1130) }\end{array}$ & $\begin{array}{l}\text { Central Dry } \\
\text { Zone }\end{array}$ & $\begin{array}{l}\text { Red soil, } \\
\text { (650 to } 675)\end{array}$ & $\begin{array}{l}\text { Irregular rainfall, water scarcity, undulatiing } \\
\text { topography, soil erosion and poor productivity. }\end{array}$ \\
\hline $\begin{array}{l}\text { Sukaligarahatti } \\
\text { (1047) }\end{array}$ & $\begin{array}{l}\text { Central Dry } \\
\text { Zone }\end{array}$ & $\begin{array}{l}\text { Red soil, } \\
\text { (500 to } 700)\end{array}$ & $\begin{array}{l}\text { Undulating topography, poor drainage and } \\
\text { water scarcity. }\end{array}$ \\
\hline $\begin{array}{l}\text { Harohalli } \\
(\mathbf{1 7 7 2 . 3 3 )}\end{array}$ & Hilly Zone & $\begin{array}{l}\text { Lateritic soil, } \\
\text { (2000 to 2500) }\end{array}$ & $\begin{array}{l}\text { Undulating and slopy land, intense rainfall, soil } \\
\text { erosion due to heavy runoff, land degradation, } \\
\text { poor productivity and water scarcity. }\end{array}$ \\
\hline $\begin{array}{l}\text { Laxmanthirtha } \\
\text { (1355.44) }\end{array}$ & Hilly Zone & $\begin{array}{l}\text { Lateritic soil, } \\
\text { (1900 to 2500) }\end{array}$ & $\begin{array}{l}\text { Fragile and undulating topography, heavy } \\
\text { runoff and soil erosion, land degradation, low } \\
\text { soil fertility and productivity. }\end{array}$ \\
\hline $\begin{array}{l}\text { Herekumbi } \\
(1019.94)\end{array}$ & $\begin{array}{l}\text { Northern Dry } \\
\text { Zone }\end{array}$ & $\begin{array}{l}\text { Black soil, } \\
(600)\end{array}$ & $\begin{array}{l}\text { Heavy runoff, high soil erosion, low soil } \\
\text { fertility, poor yield and drought }\end{array}$ \\
\hline $\begin{array}{l}\text { Wadral } \\
(901.50)\end{array}$ & $\begin{array}{l}\text { Northern } \\
\text { Transition Zone }\end{array}$ & $\begin{array}{l}\text { Black soil, } \\
\text { (735) }\end{array}$ & $\begin{array}{l}\text { Highly undulating topography, hills slopes, } \\
\text { acute water scarcity, frequent drought, high soil } \\
\text { erosion from steep slopes due to heavy runoff, } \\
\text { low moisture status in soil and low } \\
\text { productivity. }\end{array}$ \\
\hline $\begin{array}{l}\text { Herurkerenala } \\
(1626.60)\end{array}$ & $\begin{array}{l}\text { Central Dry } \\
\text { Zone }\end{array}$ & $\begin{array}{l}\text { Red soil, } \\
(<700)\end{array}$ & $\begin{array}{l}\text { Low soil depth, low moisture content and } \\
\text { fertility, soil erosion, drought, excess ground } \\
\text { water extraction and practice of traditional } \\
\text { agriculture. }\end{array}$ \\
\hline $\begin{array}{l}\text { Sugoor } \\
(1189)\end{array}$ & $\begin{array}{l}\text { Central Dry } \\
\text { Zone }\end{array}$ & $\begin{array}{l}\text { Red soil, } \\
(<650)\end{array}$ & $\begin{array}{l}\text { Shallow red soil, low moisture content and } \\
\text { fertility, soil erosion, drought, excess ground } \\
\text { water extraction and practice of traditional } \\
\text { agriculture. }\end{array}$ \\
\hline
\end{tabular}


Table.2 Watershed wise activities implemented

\begin{tabular}{|c|c|}
\hline Name of watershed & Soil and water conservation activities \\
\hline Attibylu & $\begin{array}{l}\text { Field bunds, waste weirs, water ways, diversion channels, farm ponds, } \\
\text { boulder checks and rubble checks }\end{array}$ \\
\hline Shedgar & Diversion channels, water ways, farm ponds and vented check dams \\
\hline Baladare & $\begin{array}{l}\text { Field bunds, farm ponds, waste weirs, boulder checks(BC) and rubble checks } \\
\text { (RC) and check dams }\end{array}$ \\
\hline Gandasi & $\begin{array}{l}\text { Field bunds/trench cum bunds, waste weirs, farm ponds, boulder bunds, water } \\
\text { ways and sunken ponds, shrub checks, boulder checks and rubble checks }\end{array}$ \\
\hline Bukkasagar & $\begin{array}{l}\text { Field bunds, waste weirs, farm ponds, boulder bunds, rubble checks and } \\
\text { boulder checks }\end{array}$ \\
\hline Sukaligarahatti & Field bunds, waste weirs, farm ponds, rubble checks and boulder checks \\
\hline Harohalli & $\begin{array}{l}\text { Staggered contour trenches (SCTs), farm ponds, diversion channel (DC), } \\
\text { seepage drains and water ways, rubble checks, boulder checks and vented } \\
\text { check dams }\end{array}$ \\
\hline Laxmanthirtha & SCT, water ways, farm ponds and vented check dams \\
\hline Herekumbi & $\begin{array}{l}\text { Field bunds, trenches, pipe outlets, shallow wells, farm ponds, water } \\
\text { absorption tanks (WAT), boulder checks, ravine reclamation structures (RRS) } \\
\text { and vented check dams }\end{array}$ \\
\hline Wadral & $\begin{array}{l}\text { Field bunds, water ways, farm ponds, waste weirs, shallow wells, renovation } \\
\text { of existing check dams }\end{array}$ \\
\hline Herurkerenala & $\begin{array}{l}\text { Field bunds / Trench cum bunds, waste weirs, farm ponds, loose boulder check } \\
\text { dams, rubble checks type } 1 \text { and } 2\end{array}$ \\
\hline Sugoor & $\begin{array}{l}\text { Field bunds /trench cum bunds, waste weirs, farm ponds, boulder bunds, loose } \\
\text { boulder check dams and rubble checks }\end{array}$ \\
\hline
\end{tabular}

Table.3 Watershed wise area treated with expenditure and amount spent for major activity

\begin{tabular}{|l|l|l|l|l|}
\hline $\begin{array}{l}\text { Name } \\
\text { watershed }\end{array}$ & $\begin{array}{l}\text { Area treated (ha) } \\
\text { and its percentage of } \\
\text { geographical area }\end{array}$ & $\begin{array}{l}\text { Expenditure } \\
\text { incurred } \\
\text { (Rs. in Lakhs) }\end{array}$ & $\begin{array}{l}\text { Expenditure } \\
\text { per ha } \\
\text { (Rs.) }\end{array}$ & $\begin{array}{l}\text { Major activity and } \\
\text { percentage of total } \\
\text { amount spent on it }\end{array}$ \\
\hline Attibylu & $962.88(76 \%)$ & 67.92 & 7054 & Bunding (57\%) \\
\hline Shedgar & $795.91(61 \%)$ & 20.32 & 2553 & Farm pond (47\%) \\
\hline Baladare & $1100(85 \%)$ & 64.72 & 5884 & Bunding (52\%) \\
\hline Gandasi & $864(74 \%)$ & 54.62 & 6322 & Bunding (40\%) \\
\hline Bukkasagar & $1130.27(100 \%)$ & 55.7 & 4928 & Bunding (58\%) \\
\hline Sukaligarahatti & $827.45(79 \%)$ & 45.76 & 5530 & Bunding (74\%) \\
\hline Harohalli & $1464.79(83 \%)$ & 35.58 & 2429 & SCT (20\%) \\
\hline Laxmanthirtha & $1355.44(100 \%)$ & 94.25 & 6953 & SCT (47\%) \\
\hline Herekumbi & $892.61(88 \%)$ & 48.39 & 5421 & Bunding (75\%) \\
\hline Wadral & $883.48(98 \%)$ & 40.65 & 4601 & Bunding (69\%) \\
\hline Herurkerenala & $962.88(59 \%)$ & 71.41 & 7416 & Bunding (83\%) \\
\hline Sugoor & $1060.17(89 \%)$ & 62.68 & 5912 & Bunding (54\%) \\
\hline
\end{tabular}


Table.4 Improvement in ground water level (GWL), crop yield, soil organic carbon (OC) and reduction in soil loss in watersheds

\begin{tabular}{|l|l|l|l|l|l|l|}
\hline $\begin{array}{l}\text { Name } \\
\text { watershed }\end{array}$ & $\begin{array}{l}\text { Increased } \\
\text { GWL }(\mathbf{m})\end{array}$ & \multicolumn{2}{|l|}{$\begin{array}{l}\text { Increase in Crop yield } \\
(\%)\end{array}$} & $\begin{array}{l}\text { OC in soil } \\
(\%)\end{array}$ & $\begin{array}{l}\text { Reduction } \\
\text { in soil loss } \\
(\%)\end{array}$ \\
\hline Attibylu & $61-76.2$ & $2.9-23.5$ & $4.2-14.4$ & $0.39-1.44$ & $20-40$ \\
\hline Shedgar & $30.5-36.6$ & $10-20$ & $24-32$ & $0.35-1.02$ & 50 \\
\hline Baladare & $45.7-54.9$ & $2-22.2$ & $5.8-25$ & $0.18-1.34$ & 30 \\
\hline Gandasi & $45.7-61$ & $6.1-20$ & $4.2-24$ & $0.31-0.76$ & 40 \\
\hline Bukkasagar & $61-76.2$ & $2.9-28.6$ & $13.3-25$ & $0.3-1.11$ & $30-35$ \\
\hline Sukaligarahatti & $30.5-33.5$ & $5.8-26.5$ & $3.4-20$ & $0.26-1.26$ & $20-30$ \\
\hline Harohalli & $45.7-61$ & $4-9.9$ & - & $0.64-2.57$ & 20 \\
\hline Laxmanthirtha & $5.5-6.1$ & $8.3-16.5$ & - & $0.58-2.38$ & 50 \\
\hline Herekumbi & $30.5-36.6$ & $9.1-27$ & $4-29$ & $0.23-0.78$ & 27 \\
\hline Wadral & $9.1-15.2$ & $10-24.4$ & $5-25$ & $0.27-0.89$ & $40-50$ \\
\hline Herurkerenala & $15.2-76.2$ & $9.3-33$ & $6.4-33$ & $0.07-1.40$ & $15-20$ \\
\hline Sugoor & $6.7-18.9$ & $12-26$ & $11-27$ & $0.37-1.25$ & 20 \\
\hline
\end{tabular}

Table.5 Farmers' weight (\%) on criteria due to ameliorating effect of SWC measures in watersheds

\begin{tabular}{|l|l|l|}
\hline $\begin{array}{l}\text { SI } \\
\text { no. }\end{array}$ & Criteria & Weight (\%) \\
\hline 1 & Erosion control & 19 \\
\hline 2 & Enhance fertility & 11 \\
\hline 3 & Increase in water retention & 14 \\
\hline 4 & Improve in ground water level & 4 \\
\hline 5 & Increase in crop yield & 24 \\
\hline 6 & Increase in fodder/ grass production & 8 \\
\hline 7 & Increase in cultivable area & 5 \\
\hline 8 & Labour requirement for establishment & 8 \\
\hline 9 & Maintenance cost & 7 \\
\hline & Total & 100 \\
\hline
\end{tabular}


Table.6 Farmers' ranking of SWC measures based on the criteria selected in watersheds

\begin{tabular}{|c|c|c|c|c|c|c|c|c|}
\hline \multirow{2}{*}{$\begin{array}{l}\text { Sl } \\
\text { no. }\end{array}$} & \multirow[t]{2}{*}{ Criteria } & \multicolumn{7}{|c|}{ SWC measures } \\
\hline & & $\begin{array}{l}\text { Field } \\
\text { bunding }\end{array}$ & $\begin{array}{l}\text { Waste } \\
\text { weir }\end{array}$ & $\begin{array}{l}\text { Farm } \\
\text { pond }\end{array}$ & $\begin{array}{l}\text { Boulder } \\
\text { check }\end{array}$ & $\begin{array}{l}\text { Rubble } \\
\text { check }\end{array}$ & $\begin{array}{l}\text { Check } \\
\text { dam }\end{array}$ & $\begin{array}{l}\text { Trenching } \\
*(\text { SCT })\end{array}$ \\
\hline 1 & Erosion control & 5 & 3 & 3 & 5 & 5 & 4 & 5 \\
\hline 2 & Enhance fertility & 5 & 1 & 2 & 2 & 2 & 2 & 4 \\
\hline 3 & $\begin{array}{l}\text { Increase in water } \\
\text { retention }\end{array}$ & 5 & 2 & 4 & 2 & 4 & 5 & 4 \\
\hline 4 & $\begin{array}{l}\text { Improve in ground } \\
\text { water level }\end{array}$ & 4 & 2 & 4 & 2 & 4 & 5 & 3 \\
\hline 5 & $\begin{array}{l}\text { Increase in crop } \\
\text { yield }\end{array}$ & 5 & 2 & 5 & 1 & 1 & 5 & 3 \\
\hline$\overline{6}$ & $\begin{array}{l}\text { Increase in fodder/ } \\
\text { grass production }\end{array}$ & 5 & 1 & 4 & 1 & 1 & 4 & 3 \\
\hline 7 & $\begin{array}{l}\text { Increase in } \\
\text { cultivable area }\end{array}$ & 4 & 2 & 5 & 4 & 4 & 5 & 3 \\
\hline 8 & $\begin{array}{l}\text { Labour requirement } \\
\text { for establishment }\end{array}$ & 2 & 3 & 2 & 3 & 3 & 2 & 2 \\
\hline 9 & Maintenance cost & 4 & 2 & 4 & 2 & 3 & 4 & 3 \\
\hline & Total & 39 & 18 & 33 & 22 & 27 & 36 & 30 \\
\hline & Avg. & 4.3 & 2.0 & 3.7 & 2.4 & 3.0 & 4.0 & 3.3 \\
\hline
\end{tabular}

Scores: 5 = Best, $4=$ Very good, $3=$ Good, $2=$ Average, $1=$ Not good, $*$ SCT: Staggered contour trenching

Table.7 Discount rate of $\mathrm{BC}$ ratio and respective IRR in watersheds

\begin{tabular}{|c|c|c|c|c|c|c|}
\hline \multirow[t]{3}{*}{ Name of watershed } & \multicolumn{4}{|c|}{ Discount rate of $\mathrm{BC}$ ratio } & \multirow{2}{*}{\multicolumn{2}{|c|}{$\operatorname{IRR}(\%)$}} \\
\hline & \multicolumn{2}{|c|}{$12 \%$} & \multicolumn{2}{|c|}{$15 \%$} & & \\
\hline & 10 yrs & $15 y r s$ & 10yrs & $\begin{array}{l}15 \\
\text { yrs }\end{array}$ & 10yrs & $15 y r s$ \\
\hline Attibylu & 1.88 & 2.34 & 1.65 & 2.03 & 26.46 & 29.78 \\
\hline Shedgar & 4.76 & 5.99 & 4.19 & 5.20 & 49.48 & 51.35 \\
\hline Baladare & 1.18 & 1.56 & 1.03 & 1.29 & 15.66 & 20.00 \\
\hline Gandasi & 1.77 & 1.92 & 1.64 & 1.80 & 25.05 & 25.05 \\
\hline Bukkasagar & 2.00 & 2.48 & 1.75 & 2.16 & 27.83 & 31.00 \\
\hline Sukaligarahatti & 1.65 & 2.16 & 1.44 & 1.85 & 22.91 & 26.74 \\
\hline Harohalli & 2.17 & 2.43 & 1.89 & 2.14 & 29.82 & 31.97 \\
\hline Laxmanthirtha & 2.80 & 3.55 & 2.80 & 3.55 & 34.73 & 37.44 \\
\hline Herekumbi & 2.08 & 2.58 & 1.82 & 2.24 & 28.74 & 31.88 \\
\hline Wadral & 1.07 & 1.25 & 0.96 & 1.11 & 13.92 & 17.60 \\
\hline Herurkerenala & 1.04 & 1.32 & 0.91 & 1.14 & 12.94 & 17.56 \\
\hline Sugoor & 1.56 & 1.82 & 1.40 & 1.62 & 23.73 & 26.63 \\
\hline Avg. & 2.0 & 2.5 & 1.8 & 2.2 & 25.9 & 28.9 \\
\hline
\end{tabular}


Fig.1 Location map of study area

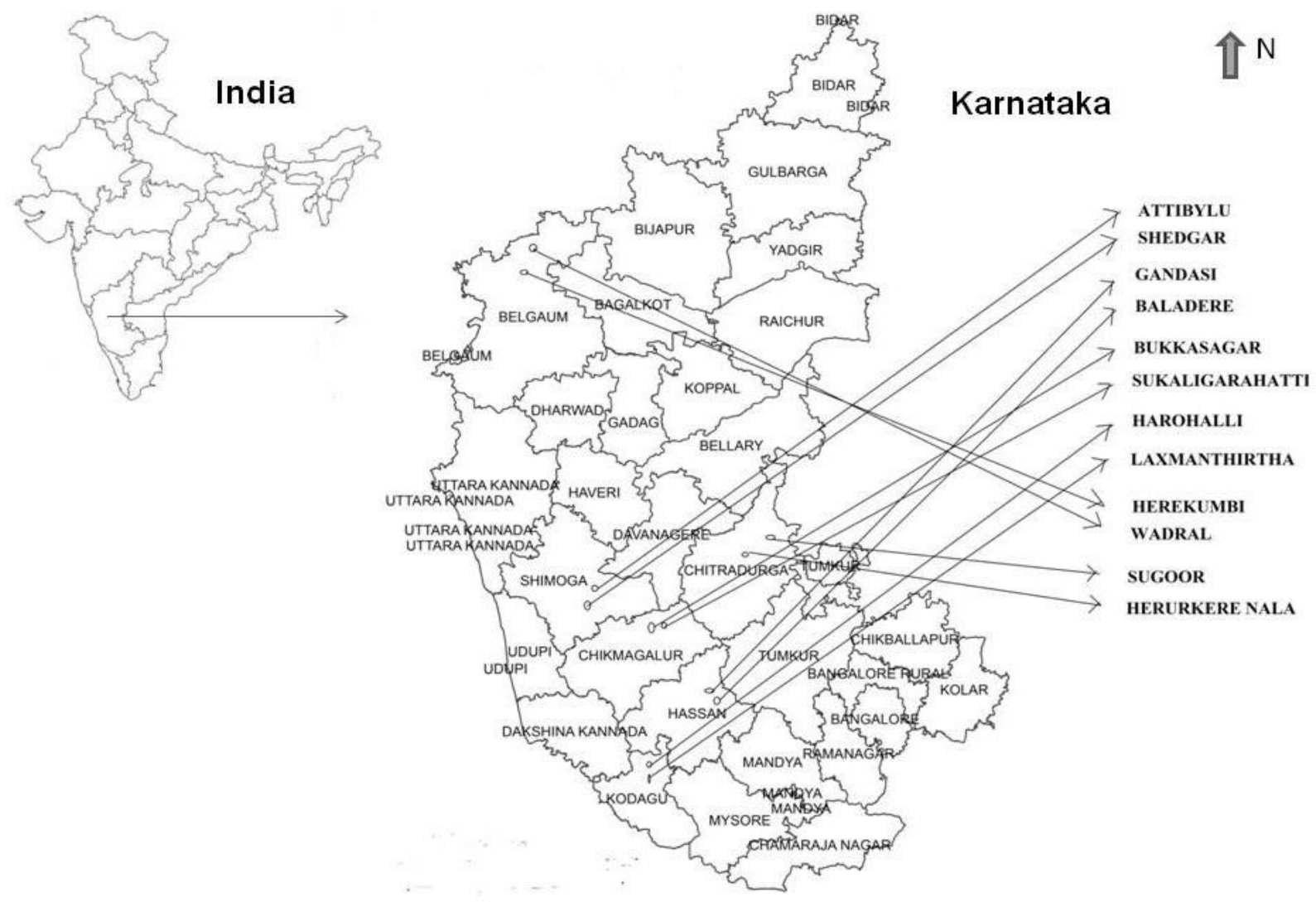

In 9 watersheds, field bunding was the major treatment with expenditure varied from 40$83 \%$ of total spent amount. The details of area treated, expenditure and amount spent for major activity watershed wise is given in Table 3.

\section{Impacts of SWC measures}

As a result of intensive field bunding in watersheds, it almost restricted the runoff to flow out from the crop fields, increased the opportunity time and helped in retaining healthy soil moisture status in field. It attributed to improved crop performance and yields in watersheds. The existing bore wells and open wells were recharged due to construction of farm ponds and drainage line treatments and it resulted in $10-15 \%$ increase in net sown area due to assured irrigation.
Due to implementation of SWC measures, overall crop yields increased in all 12 watersheds and found varied from 3 to $33 \%$ both in rainfed land and irrigated land. Higher yield was found in chilly, cotton and sorghum due to sowing of hybrid variety, applying protective irrigation and better management practices. The average soil organic carbon content also improved and observed to be varied form low $(0.07 \%)$ to high $(2.57 \%)$ in upstream and downstream catchments of the watersheds. In nine watersheds, water level in bore wells was improved and it ranged from 15.24 to $76.2 \mathrm{~m}$ below the ground with an average increase of $0.6-4.0 \mathrm{~m}$ in different watersheds. In Laxmanthirtha, Wadral and Sugoor watersheds, in open wells, water level occurred just 5.5-18.9 $\mathrm{m}$ below the ground during summer and it shows visible augmentation in water table. In all 
watersheds, due to presence of SWC measures, runoff was reduced and resulted in controlled soil erosion. The average soil loss reduced in watersheds varied from 15 to $50 \%$. Siltation and vegetation establishments found near most of the structures and it indicates effectiveness of conservation measures and control of land degradation. As a result of implementation of SWC engineering measures, a total of 2,63,706 man days of direct employment was generated valued about Rs 3.95 crores (when calculated @ Rs $150 /$ man day) and it considerably helped in decrease in migration (15\%) of small and marginal farmers from watersheds. The positive effect of SWC measures on ground water level, productivity, soil organic carbon and soil loss is given in Table 4.

Sikka et al., (2014) and Palanisami and Kumar (2009) reported that watershed treatment activities improve conservation of soil and moisture, improve and maintain the fertility status of soil and also reduce soil and water erosion. Madhu et al., (2016) reported that due to intensive field bunding and other soil water conservation (SWC) measures taken up in the crop lands, the average estimated runoff in the watershed decreased to $14.6 \%$ from $24.4 \%$. In addition, due to construction of different water harvesting structures, 24.2 ha was brought under protective irrigation and the average water table depth raised by $0.18 \mathrm{~m}(5.9 \%)$ and the depth of water storage in thewell increased by $0.17 \mathrm{~m}(17.8 \%)$. Rise in water table and depth of water storage in well was attributed to increased base flow due to soil and water conservation measures in the watershed areas (Schilling et al., 2008).

\section{Preferences of farmers for adopting various SWC practices}

Using multiple objective decision support (MODS) weighting technique employing
Fixed point scoring and Rating method as discussed earlier, the farmers feedback on different criteria/objectives selected were taken and their weight on said criteria and ranking of different SWC measures implemented based on the criteria selected are given in Table 5 and 6 . From the weights given by farmers, highest score was for crop yield followed by erosion control, water retention and fertility. Least weight was given to ground water level which indicates less ground water recharge and benefit out of it. This might be due to low yielding of existing bore wells and continuous declining of water level in bore wells due to less rainfall over the years. From the farmers ranking on SWC measures, it shows that field bunding is most preferred followed by check dam, farm pond and trenching. Waste weir was least preferred and it might be due to rare instance of water impoundment in the filed up to highest flood level. Research show that farmers are sensitive to economic returns and invest in technologies that offer highest net economic returns (Shiferaw et al., 2009). Their decision to invest in SWC technologies is affected by the (perceived) profitability of the technology (Getinet, 2008). Several research studies (Kerr et al., 1999; Reddy, 1994; Shah, 1999) reveal that farmers' practiced on large scale traditional SWC measures that involve relatively less cost such as boundary bunds, water ways, outlet for excess water, in addition to compost manuring, sowing across slope, etc.

\section{Economic analysis}

The $\mathrm{BC}$ ratio and IRR for all twelve watersheds was calculated at $12 \%$ and $15 \%$ discount rates for 10 and 15 years period (Table 7). The $\mathrm{BC}$ ratios obtained was more than unity for all the watersheds and it indicates that the investment made for the watershed development is a profitable venture. Since the IRR calculated was also 
higher than the discount rates in all scenarios, it strongly supports the above statement. When we take the average of $\mathrm{BC}$ ratios and IRR for all the 12 watersheds, the $\mathrm{BC}$ ratio is more than 2, i.e. 2.5 and 2.2 at $12 \%$ and $15 \%$ discount rates at 15 years with respective IRR of 25.9 and 28.9 for 10 and 15 years. It shows that if farmers maintain the SWC structures for 15 years, they can have higher $\mathrm{BC}$ ratios and IRR from the watershed treatment. Madhu et al., (2016) calculated the Benefit Cost Ratio (BCR) at $10 \%$ discount rate as 1.16:1 and Internal Rate of Returns as $19.5 \%$ for a watershed in Odisha and revealed that the BCR and IRR for arable and non-arable lands suggest the economic viability of the project. The financial analysis of impact of watershed development indicated that the return to public investment such as watershed development activities were feasible (Palanisami and Kumar, 2009).

From this experience of Evaluation study of watershed projects in Karnataka, it is inferred that SWC practicesplay vital role for the effective resource conservation, its management and vis-à-vis livelihood augmentation in a watershed. The results reveal that after implementation of SWC measures, there are many positive impacts on productivity, resource use and ecosystem. The results also reinforced that watershed management is a profitable venture and it considerably helps in land degradation and reducing the migration from the watersheds. There is a need to strengthen people's participation in planning and execution of the SWC practices for improving their economic efficiencies. Hiring of contractor and machines in execution of SWC practices should be preferably avoided for economic utilization of funds and more employment generation. There should be flexibility in design, estimation and costing in respect of different SWC structures as per the site suitability and practical need, and should not be limited by other constraints. Prior to implementation of the SWC measures, farmers' preference should be given due importance since during adoption of SWC measures, farmers give more priority to economic returns as compared to other tangible benefits. From the evaluation point of view, though many of SWC practices are profitable, it is essential to concentrate on adequate internal incentives and wide objectives of farmers for long-term sustenance of SWC measures in a watershed.

\section{Acknowledgements}

The authors are grateful to Dr. P.K. Mishra, Director, ICAR-Indian Institute of Soil Water Conservation, Dehradun for permitting to undertake this study. The support received from local NABARD authorities is also thankfully acknowledged.

\section{References}

Adimassu, Z., B. Gorfu, D. Nigussie, J. Mowo and K. Hilemichael. 2013. Farmers' preference for soil and water conservation practices in Central highlands of Ethiopia. African Crop Science Journal, 20, 781-790.

Angima, S.D., D.E. Stott, M.K. O’Neill, C.K. Ong and G.A. Weesies. 2003. Soil erosion prediction using RUSLE for central Kenya highland conditions. Agric. Ecosys. Environ., 97, 295-308.

Boardman, A. E., D. H. Greenberg, A. R. Vining and D. L. Weimer. 2006. CostBenefit Analysis, Concepts and Practice, Third Edition, Upper Saddle River, New Jersey: Pearson Education, Inc.

Dass, A., S. Sudhishri, U. S. Patnaik and N. Lenka. 2009. Effect of agronomic management in watershed productivity, impact indices, crop diversification and 
soil fertility in Eastern Ghats of Odisha., J. Soil Water Cons., 8, 34-42.

Department of Land Resources Report of the Technical Committee on Watershed Programmes in India. 2006. From Hariyali to Neeranchal, Department of Land Resources. Ministry of Rural Development, Government of India.

Deshpande, R. S. and V. R. Reddy.1991. Differential impact of watershed based technology: Some analytical issues. Indian J. Agric. Econ., 46, 261-269.

Dhyani, B. L., J. S. Samra, R. Babu and N. Kumar. 2001. Environmental payoff integrated watershed management programme in Garhwal Himalaya- A case study of ORP Fakot, J. Soil Water Cons., 45, 141-147.

Fadim, Y. and T. Baycan. 2015. Stakeholder participation to watershed management: A case study from Beysehir Lake basin. J. Environ. Biol., 36, 221-228.

Getnet, K.: From market liberalisation to market development. 2008. The need for market institutions in Ethiopia. Economic Systems, 32: 239-252.

Ginttinger J. P. 1994. Economic Analysis of Agricultural Projects, John Hopkins University Press.

Gramlich, E. M. 1997.A Guide to CostBenefit Analysis, Englewood Cliffs, New Jersey: Prentice Hall.

Hajkowicz, Stefan A., Geoff T. McDonald, Phil N. Smith. 2000. An evaluation of multiple objective decision support weighting techniques in natural resource management. J. of Environ. Plng. and Mgmt., 43, 505-518.

Jenkins G. P, C. Y. K. Kuo and A. C. Harberger. 2011. "Discounting and Alternative Investment Criteria" Chapter 4, Cost-Benefit Analysis for Investment Decisions.

Joshi, P. K., B. Pangare, V. Shiferaw, S. P Wani, J. Bouma, and C. Scott. 2004. Socioeconomic and policy research on watershed management in India: Synthesis of past experiences and needs for future research. Global Theme on Agroecosystems Report no. 7 Patancheru 502324, Andhra Pradesh, India: International Crops Research Institute for the Semi-Arid Tropics, $\mathrm{p}$. 88.

Joshi, P.K., A. K. Jha, S. P. Wani, J. Laxmi, and R. L. Shiyani. 2005. Meta-analysis to assess impact of watershed program and people's participation. Research Report 8, Comprehensive Assessment of watershed management in agriculture, International Crops Research Institute for the Semi-Arid Tropics and Asian Development Bank, p. 21.

Joshi, P.K., A. K. Jha, S. P. Wani, T. K. Sreedevi and F. A. Shaheen. 2008. Impact of Watershed Program and Conditions for Success: A MetaAnalysis Approach. Global Theme on Agroecosystems International Crops Research Institute for the Semi-Arid Tropics, Patancheru.

Kerr, J., G. Pangare, V. Lokur, and P.J. George. 1999. Effects of Watershed Project subsidies on soil and water conservation investments in India's semi-arid projects, In "Incentives in Soil Conservation; From Theory to Practice" (eds) Sanders D.W., Huszar P.C., Sombatpanit S. and Enters T. p295-308 Oxford \& IBH Publishing Co. Pvt. Ltd. New Delhi.

Kerr, John, G.Pangare, V. L.Pangare, and P. J. George. 2000. An evaluation of dryland watershed development projects in India, EPTD Discussion Paper No.68, International Food Policy Research Institute, Washington. D. C.

Madhu, M., B. S. Naik, P. Jakhar, H. C. Hombe Gowda, P. P. Adhikary, K. P. Gore, D. Barman, and G. B. Naik. 2016. Comprehensive impact assessment of 
resource conservation measures in tribal watershed of eastern region of India. $J$. of Environ. Bio., 37, 391-398.

NAAS-ICAR. 2010. Degraded and Waste Lands of India - Status and Spatial Distribution, Indian Council of Agricultural Research, New Delhi. Published by Directorate of Information and Publications of Agriculture, ICAR, New Delhi. pp-167.

Naik, B. S., J. C. Paul, B. Panigrahi, and B. C. Sahoo. 2015. Soil erosion assessment from farming lands of Eastern Ghat Region of Odisha. Ind. J. of Soil Cons., 43: 33-37.

Nijkamp, P., P. Rietveld and H. Voogd.1990. Multicriteria Evaluation in Physical Planning. North-Holland. Amsterdam.

Ninan, K. N. and S. Lakshmikanthanthamma. 2001. Social Cost-Benefit Analysis of a Watershed Development Project in Karnataka, Vol.30 No.3, Royal Swedish Academy of Sciences.

Palanisami, K. and D.S. Kumar. 2009. Impacts of watershed development programmes: Experiences and Evidences from Tamil Nadu. Agricul. Econ. Rese. Rev. 22 (Conference Number): 387-396.

Reddy B.V.C. 1994. Investment In Soil And Water Conservation: An Analysis Of Its Impact In The Kalyanakere Watershed Project. $\mathrm{PhD}$ thesis, University of Agricultural Sciences, Bangalore, India.

Rockström, J., N. Hatibu, Y. TheibOweis and S. P. Wani. 2007. Managing water in rain-fed agriculture. In: Water for food, water for life: A comprehensive assessment of water management in agriculture (Ed. D. Molden). London, UK: Earthscan and Colombo, SriLanka: International Water Management Institute, pp. 315-348.

Schilling, K. E. and M. Helmers. 2008. Effects of subsurface drainage tiles on stream flow in Iowa agricultural watersheds: Exploratory hydrograph analysis. 4497-4506.

Shah, A. 1999. The acid test: will beneficiaries contribute? In: Farrington, J., Turton, C. and James, AJ. (eds.). Participatory Watershed Development: Challenges for the Twenty First Century. Oxford University Press, New Delhi.

Shah, A.2001. Who benefits from participatory watershed development? Lessons from Gujarat, India, IIED Gatekeeper Series 97 IIED, London.

Sharda V. N, G. P. Juyal, C. Prakash and B. P. Joshi. 2007. Training Manual Soil conservation and watershed management, Vol-II, (soil water conservation engineering).Central Soil and Water Conservation Research and Training Institute (CSWCRTI), Dehradun, Uttaranchal, pp. 1-410.

Sharda, V. N., P. Dogra and C. Prakash. 2010. Assessment of production losses due to water erosion in rainfed areas of India. J. of Soil and Water Cons., 65: 79-91.

Shiferaw, B., J. Okello, and R. V. Reddy. 2009. Adoption and adaptation of natural resource management innovations in smallholder agriculture: Reflections on key lessons and best practices. Environment, Development and Sustainability, 11:601-619.

Sikka, A. K., M. Madhu, Subhash Chand, D.V. Singh, V. Selvi, P. Sundarambal, K. Jeevarathanam and M. Murgaiah. 2014. Impact analysis of participatory integrated watershed management programme in semi-arid region of Tamil Nadu, India. Ind. J. Soil Cons., 42: 98106.

Slegers, M. F.W. 2008. If only it would rain: Farmers' perceptions of rainfall and drought in semi-arid central Tanzania. J. of Arid. Environ., 72, 2106 - 2123.

Walkely, A. and I. A. Black. 1934. An examination of Degtjareff methods for 
determining soil organic matter and a proposed modification of the chromic acid titration method. Soil Science, 37, 29-38.

Wani, S. P., P. Pathak, L. S. Jangawad, H. Eswaran and P. Singh. 2003. Improved management of vertisols in the semiarid tropics for increased productivity and soil carbon sequestration. Soil Use Manage., 217-222.

Wani, S. P., T. K. Sreedevi, P. Pathak, P. Singh and H. P. Singh.2001. Integrated watershed management through a consortium approach for sustaining productivity of rainfed areas: Adarsha watershed, Kothapally, India, Andhra Pradesh: A case study. Paper presented at the Brainstorming Workshop on Policy and Institutional Options for Sustainable Management of Watersheds, ICRISAT, Patancheru, Andhra Pradesh, India.

\section{How to cite this article:}

Bhupendra Singh Naik, Sekhargouda Lingannagouda Patil, Anurag Raizada, Hrittick Biswas, Suresh Kumar, Mundre Ningappa Ramesha, Wontakal Muralidhar, Keshava Kumar Reddy and Mohan Kumar, P. 2018. Watershed Evaluation and Farmers' Preference - An Experience from Watershed Projects in Karnataka (India). Int.J.Curr.Microbiol.App.Sci. 7(09): 2661-2676. doi: https://doi.org/10.20546/ijcmas.2018.709.332 